\title{
From "Secreit” Script to Public Print: Punctuation, News Management, and the Condemnation of the Earl of Bothwell
}

\author{
Jeremy J. Smith
}

\begin{abstract}
Documents associated with the fall of James Hepburn, Earl of Bothwell, in 1567 offer a rare insight into how texts were adapted for different purposes and readerships. Initially recorded in the manuscript "Register of the Acts of the Privy Council of Scotland," these texts subsequently appeared as printed broadsheets for public display in prominent places. They are the first Scottish documents of their kind known to have undergone this process of transition. As the texts passed from one medium to another, their form and punctuation were changed, mirroring their altered function. In this essay, Jeremy J. Smith shows that their differences in such formal features align quite precisely with the changing uses of literacy in early modern Scotland. KEY WORD S: Privy Council of Scotland; Robert Lekpreuik; litterae notabiliores; sixteenth century Scottish proclamations; sixteenth-century punctuation
\end{abstract}

IN THE SUMMER OF 1567, the Privy Council of Scotland met at the great palace of Holyrood in Edinburgh to deal with an emergency. The council was composed of the kingdom's most powerful magnates and officers of state and usually governed, at least officially, in conjunction with the monarch or (if the monarch was too young) a regent. However, on this occasion no such person was available. The "lordis of secreit counsale," as they were usually styled in the "Register" of their acts, were on their own.

The reason is well known. On May 15, 1567, Mary, Queen of Scots, had married James Hepburn, fourth Earl of Bothwell, who had been divorced the previous month by his wife, Lady Jean Gordon, on the grounds of his adultery with a maidservant. ${ }^{1}$ A glamorous, violent man, Bothwell is, quite rightly, one of the most notorious figures in sixteenth-century Scottish history. He had almost certainly planned and been

1. John Guy, My Heart Is My Own: The Life of Mary Queen of Scots (London, 2004), 330.

Pp. 223-238. (@2017 by Henry E. Huntington Library and Art Gallery. ISSN 0018-7895 | E-ISSN 1544-399x. All rights reserved. For permission to photocopy or reproduce article content, consult the University of Pennsylvania Press Rights and Permissions website, http://www.upenn.edu/pennpress/about/permissions.html. 
involved in the murder of Henry Stewart, Lord Darnley, Mary's second (rather unsatisfactory) husband, in February 1567, at Kirk o' Field in Edinburgh. Soon after Darnley's murder, painted placards that implicated Bothwell and Mary in the killing appeared in various public locations in Edinburgh. One subtly pornographic example of these precursors of the political cartoon depicted Bothwell as a hare (from his family's heraldic beast), surrounded by swords as phallic symbols; the queen appeared as a crowned mermaid, carrying - instead of orb and scepter-a net to catch unwary sailors and an anemone, since classical times emblematic of female genitalia. ${ }^{2}$

Subsequent to Darnley's death, Bothwell abducted Mary-possibly with her consent-and, at Dunbar Castle, allegedly raped her; she and Bothwell, newly created Duke of Orkney for the occasion, were then married at Holyrood. Bothwell briefly rejoined Privy Council meetings (having been a member since 1561); he is recorded attending on several occasions early in 1567. However, the other lords of Scotland, unimpressed with Bothwell's new position, rose against the couple. On June 15, there was an armed confrontation at Carberry Hill, near Musselburgh. Mary was captured and imprisoned at Lochleven Castle, where she was forced to abdicate in favor of James VI, her son by Darnley. Bothwell fled into exile, where he spent the final ten years of his life imprisoned, in conditions of increasing severity, by Frederick, King of Denmark. 3

The lords responded to what they perceived as their monarch's abduction not only by force-something to which they were used-but also by a series of performative declarations. They issued in quick succession a series of proclamations: a declaration of martial law, on June 11; a formal condemnation of Bothwell, on June 12; and on June 26, after the events at Carberry Hill, a demand for Bothwell's apprehension. These proclamations, interestingly, insisted upon the lords' status, independent of that of the monarch, in the government of the kingdom. Such performative declarations were not unusual; to take an obvious example, the great Declaration of Arbroath of 1320, asserting Scottish independence, had a similarly public function. But the appearance of the proclamations associated with the Bothwell crisis has an even wider significance for the history of literacy in the public sphere: they seem to be the first surviving Scottish documents of their kind to be reproduced in print.

\section{额}

The three proclamations just described were reproduced in a broadsheet ("broadside") format, in which a single sheet was printed on one side; this sheet could be stuck to a wall in a public place, inserted into a codex miscellany, or passed from hand to hand. Such documents were of course ephemeral in the manner of modern newspapers and have survived rarely in comparison with printed books. However, a few copies remain of the three proclamations issued in June 1567, all produced in the workshop of Robert Lekpreuik (or Lekprevik), the first truly successful Scottish printer. 
The year 1567 seems to have marked a departure in Lekpreuik's career. Until that date, he had focused on producing a series of substantial public works. His output included acts of Parliament and works commissioned by the Protestant Kirk, including the 1561 Confessioune of the fayht and doctrin beleued and professed by the Protestantes of the Realme of Scotland and, in 1566, the first book printed in Gaelic: Foirm na nvrrnvidheadh (a translation of the new liturgy, the Book of Common Order). Lekpreuik had therefore an established reputation as a printer working for the Protestant party in the production of works for godly purposes, catering to a thoughtful vernacular readership. In January 1567 , he was officially nominated as the king's printer, granted the monopoly not only for printing acts of Parliament but also a string of key textbooks, including The buik callit the Omeleyis [Homilies] for reidaris [readers] in kirkis and The generall grammer to be usit within scolis [schools] of this realme for eruditioun of the youth. 4

However, 1567 also saw Lekpreuik clearly responding nimbly to widespread and justifiable anxieties about urgent public affairs. R. Dickson and J. Edmond record Lekpreuik as producing at least seven items during this year, all broadsheets printed in black-letter type: ephemera with political significance. 5 This list may be supplemented from the National Library of Scotland's online Scottish Books 1505-170o (Aldis Updated), which adds two further items. ${ }^{6}$ Six of these texts were controversial poems by Robert Sempill, the Protestant versifier and propagandist. The remaining three broadsheets were the proclamations associated with the Bothwell crisis.

The broadsheet format seems to have been something comparatively new for Scotland in 1567; those broadsheets printed by Lekpreuik are the oldest Scottish examples surviving. However, the format is attested elsewhere well before that date. Singlesheet indulgences, for instance, had been among the very earliest outputs of the German pre-Reformation printing presses. By as early as 1493, the media-savvy Holy Roman Emperor Maximilian I developed the practice of printing his proclamations as broadsheets; he even, it is alleged, commissioned printed propaganda sheets to be transported into a besieged city within Venetian territory by balloons, which were to be shot down by his archers in order to permit the beleaguered inhabitants to read them.7 Along with so-called Flugschriften-cheaply produced small pamphlets consisting of only a few leaves-such broadsheets represent the beginnings, albeit somewhat uncertain, of the newspaper trade.

Matters were less developed in Scotland and arguably less sophisticated; the Privy Council certainly did not deploy balloons. The 1567 broadsheets were nevertheless public documents, for display in such places as the Tolbooth near St. Giles's kirk in

4. Robert Dickson and John Philip Edmond, Annals of Scottish Printing (Cambridge, 189o), 201.

5. Ibid., 232-35. Dickson and Edmond identify three further items that, although undated, were probably printed by Lekpreuik in 1567 . These are, again, poems by Sempill in broadsheet form (ibid., 267-78).

6. See http://www.nls.uk/catalogues/scottish-books-1505-170o/main\#a156o, accessed on April 12, 2017. References to Aldis Updated in this article are by catalogue number.

7. Andrew Pettegree, The Book in the Renaissance (New Haven, Conn., 2010), 131-32. 
Edinburgh in the manner of the modern "fly-poster"; for circulation by hand; or for declamation by "ane Maser or officiar of armes at ye marcat croces of Edinburgh perth dunde sanctandrois striueling glasgow and vyeris [other] places needful." 8 The proclamations seem to have been an "official" element in the propaganda campaign that was developing against Mary from the late 1560 s onward, whose "unofficial" expression was represented by the Sempill poems. The links between the two are clear. As Cathy Shrank has noted, "Printing polemic as broadsides ... as Lekpreuik did, helps create the illusion of a popular voice"; Shrank points out the reward that Lekpreuik achieved for his hard work: "by January 1568 he had been designated 'our soverane lordis imprentar,' with exclusive rights to print all official material for twenty years."9

We are fortunate with these proclamations in that we can trace their sources quite directly. They are verbatim printed versions of texts that survive in manuscript form elsewhere: in the "Register of Acta of the Privy Council of Scotland," the formal record book of the Privy Council's meetings dealing with public or state business, which was sustained (with a break for the Interregnum in the 1650s) until 1708, just after the Union of Parliaments. It is now PC1 in the National Records (formerly Archives) of Scotland in Edinburgh. The texts from which the proclamations derive are in volume 5 (June 1567-December 1569), written in a neat Scottish secretary script with marginal notes in textura (sometimes referred to as "text hand"). ${ }^{10}$ The marginal notes were added close to the time of composition, capturing the fast-moving events of that tumultuous time. The marginal notes are often brief. One reads simply "Proclamation," another reads "That nane resset [shelter] the erl bothuile," while a third lists "Persons to be tormentit," referring to those suspected of murdering Darnley; the verb-forms in the marginal note suggest that the torture has yet to take place, although the "persons" have already been "takin and apprehendit."11

The "Register" does not represent the ebb and flow of discussion, in the manner of the modern parliamentary Hansard, the written (and subsequently printed) record of discussions that has been a feature of British parliamentary practice since the early nineteenth century. Nor is it entirely like the minutes of a modern governmental com-

8. Cited from the manuscript version of the proclamation of June 12, 1567 (Privy Council: Register of Acta, PC1, vol. 5, p. 2, National Records of Scotland, Edinburgh [hereafter NRS]).

9. Cathy Shrank, “'This fatall Medea,' 'this Clytemnestra': Reading and the Detection of Mary Queen of Scots," Huntington Library Quarterly 73 (2010): 523-41 at 535-36.

10. For a description of the characteristics of such scripts, see Grant G. Simpson, Scottish Handwriting 1150-1650 (East Linton, U.K., 1998).

11. Those unfortunate individuals to be "put in ye Jrnis and turmentis" are listed in the marginalia as "Williame blacater James edmonstoun Johne blacater and mynart freis." The first three were all well-known "Persons" in Bothwell's service; William Blackadder was a sea captain, while the others were members of his crew. All were eventually executed for involvement in the murder of Darnley, except for Mynart Freis, a Swedish sailor, who seems to have survived because of his nationality; Bothwell as admiral of Scotland had issued him with a safe-conduct on the basis of a letter of marque given to Freis by the king of Sweden. See Robert Gore-Browne, Lord Bothwell: A Study of the Life, Character and Times of James Hepburn, 4th Earl of Bothwell (London, 1937), 395. The men were described by the humanist and political controversialist George Buchanan as "famous robbers and pirates" (quoted in Gore-Browne, Lord Bothwell, 255). 
mittee, which tidy up discussion in order to trace the path to the particular decision made. Rather, the "Register" represents the last part of such a discussion: a written record of the decision arrived at. Consequently, it supplies not only a source of precedents to aid future decision-making but also has a clear role as an agreed, mutually witnessed basis for action. The "Register" is therefore an important element in the developing professionalization of Scottish government: a way of placing the verbum regis within a clear framework of governance and of constraining the temptations of oral, unexamined decision-making to which prince or council, sometimes asserting the virtues of "flexibility," feels subject from time to time.

Whereas the function of the "Register" was essentially an exercise in evolving good governance, the function of a printed proclamation was different: the printed documents were acts of public propaganda, attempts to engage the populace on the side of the issuers. Proclamations also enforced obedience to the crown and government, in this case the Privy Council. We are therefore in the position with these texts of being able to trace their passage from script to print, and from the comparatively private ("secreit") arena of governance to the public sphere. And as these texts pass from one medium to another, key aspects of their form change, mirroring their new function and reflecting a significant development in the uses of literacy at a crucial transitional moment in Scottish history, as the traditional loyalties of the late medieval period were replaced by the new imperatives of a reformed state and Kirk.

额

An edited and abridged version of the manuscript "Register" has been published as The Register of the Privy Council of Scotland. This edition is essentially a historian's tool containing a mixture of substantial quotation and summary; because of their significance, the Bothwell documents are quoted in full, but modern punctuation has been added. ${ }^{12}$ The student who reads these proclamations in Burton's edition will, therefore, miss a distinctive feature of the editions just presented: namely, their deployment (or not) of marks of punctuation (which may be taken to include the use of litterae notabiliores, i.e., capital letters).

The reason for this intervention is clear: Burton and subsequent modern editors of the Register saw their role as to offer modern readers easy access to their own interpretation of the text, and to that end they introduced modern conventions of punctuation and layout. Such modern conventions, codified since the eighteenth century in printers' manuals or school textbooks, are a form of parsing whereby the perceived grammatical structure of the original can be more easily apprehended. Thus, in Burton's edition, as in present-day practice, full stops or periods mark the ends of sentences; semicolons are used in place of conjunctions to link main clauses when an equiparative comparison is sought; and commas are used in lists or to link subordinate to main clauses. Such editions are extremely useful for modern readers, and much

12. The Register of the Privy Council of Scotland, vol. 1, A.D. 1545-1569, ed. John Hill Burton (Edinburgh, 1877). 
more immediately approachable than diplomatic transcriptions that reflect the layout and punctuation practices of the original.

There are, however, problems with such interventionist approaches to older texts. The imposition of modern grammatical punctuation imposes modern notions of what is well-formed syntax onto texts dating from a time with different conventions and aesthetic principles. William Sherman has pointed out that, in the early modern period (and indeed before, as part of the inheritance from antiquity), there was "a fundamentally different understanding of the nature and function of sentences and the use of colons within them, one poised between written and spoken speech and capable of a length and complexity that we are no longer trained to tolerate." 13 Sherman illustrates the difference between early modern and present-day practice through a comparison of the punctuation of a Shakespearean sonnet in the 1609 edition with the usage adopted in a modern "fine" print from 2009. In the former, there is only one full stop or period mark, at the very end of the sonnet, while in the latter full stops have been introduced at the end of each quatrain (contrasting with the colon marks used in the 1609 edition). Sherman points out that the 1609 punctuation, whoever introduced it, represents a particular early modern usage in which the "single idea" of which a sentence should be composed (according to rhetorical theory developed from antiquity onward) is not complete until the end of the poem. Indeed, the sentence (sententia) was essentially a semantic notion: the idea, thought, or opinion that was being expressed. The linguistic means of expressing the sententia was the periodus, which prefigures the modern U.S. adoption of the term period to refer to the mark of punctuation flagging the end of a modern sentence. ${ }^{14}$ In other words, something is lost as well as gained through the modernizing editorial process.

Present-day English arbiters of style emphasize balance, clarity, and pithiness in prose, qualities that derive essentially from the eighteenth century (such considerations underpin, for instance, George Orwell's famous discussions of style in "Politics and the English Language"). ${ }^{15}$ But sixteenth-century tastes were different, and these tastes can be illustrated from Scottish, as well as English, texts. Some sixteenth-century authors, traditionalists, looked back to the paratactic styles of the earlier medieval period, in which main clauses were linked by coordinating conjunctions such as "and"; the early Scottish translation of the Bible, undertaken by the Ayrshire Lollard Murdoch Nisbet during the 1530s, is an example of such writing. An illustration from Nisbet's Bible follows. Although subordinate constructions are present (flagged by the words quhen, quham, quhare [when, whom, where]), there are no fewer than eight occurrences of and (e) or \& in this short passage alone (emphases added):

13. William Sherman, "Punctuation as Configuration; or, How Many Sentences Are There in Sonnet 1" (and references there cited), in Early Modern Literary Studies 21 (2013), accessed on August 9, 2015, https://extra.shu.ac.uk/emls/si-21/o4-Sherman_Punctuation as Configuration.htm.

14. For this terminology, see further Malcolm Parkes, Pause and Effect: A History of Punctuation in the West (London, 1992), 306-7.

15. George Orwell, Shooting an Elephant, and Other Essays (London, 1950). 
Ande in aan day of die wolk [week] Marie Magdalene com airlie [early] to ye graue quhen it was 3 it mirk [yet dark] And scho saw ye staan [stone] mouet away fra ye graue Tharfor scho ran and com to Symon petir and to ane vther discipile quham Jesus luvit and sais to yame: yai haue takin ye Lord fra ye graue And we wate nocht [know not] quhare yai haue laid him Tharfore petir went out \& yat ilk vyir [other] discipile: \& yai com to ye graue: ${ }^{16}$

Others adopted the so-called trailing style, whereby subordinate clauses were added somewhat promiscuously to an opening main clause. Robert Lindsay of Pitscottie's "The Historie and Cronikles of Scotland," completed between 1579 and 1586, is an example, as is demonstrated by the following passage describing the birth of Siamese twins. We might note the use of words such as quhilk, quho, quhairby (which, who, whereby), and nonfinite verb-forms such as perteinand (pertaining), all deployed to introduce subordinate constructions:

in this meane tyme thair was great marvell sene in scottland ane bairne [child] was borne raknit [reckoned] to be ane man chyld Bot frome the waist wpe [up] was tuo fair persouns witht all memberis and protratouris [forms] perteinand to tua bodyis [...] Bot frome ye waist done they war bot on personage \& could not weill knaw be ye ingyne [wit] of man quhilk of ye tua bodyis ye legis [legs] \& previe memberis proceidit not witht standing ye kingis majestie gart tak [caused to take] great cure \& deliegence upoun ye wpbringing of thir [these] tuo bodyis in ane personage gart nurische them \& leir [teach] them To pley \& singe wpoun ye Instrumentis of musick quho war become in schort tyme werie [very] Ingeneous \& cunning in ye art of musick quhairby they could pleay and singe tuo pertis ye on ye tribill ye wyer the tennour quhilk was werie dulse [sweet] \& melodious to heir ye Common pepill, quho treatit yame wondrous weill[.] ${ }^{17}$

Yet others attempted to model their prose style on classical models, adopting "Ciceronian" or "Senecan" styles. In the former, the complex periodization and complex hypotaxis possible in an inflected language such as Latin were transferred to the vernacular; such a transfer required considerable stylistic adroitness and was comparatively rarely adopted (a good example of such prose in Scotland is George Buchanan's

16. John 20:1-3. Transcribed from Egerton 288, fol. 107r, British Library. For discussion of all these texts, with extensive transcriptions, see Jeremy Smith, Older Scots: A Linguistic Reader (Edinburgh, 2012); for this text, see p. 63. The form " $y$ " is used for both the letter $y$ and the letter thorn since Scottish (and indeed northern English) scribes did not generally distinguish the two letters, and the letter yogh has been retained, e.g., in "3it."

17. Transcribed from Laing III.218, fols. $78 \mathrm{v}-79$ r, Edinburgh University Library, with interpolations silently incorporated. For a full transcription of this passage with discussion, see Smith, Older Scots, 63. 
satirical The Chameleon [1570], composed by an author who has a claim to being Scotland's leading Latinist). ${ }^{18}$ Senecan prose, though retaining the authority of a Latin model, which was important for Renaissance writers to assert, was by contrast looser and plainer, offering a balance between longer and shorter periods, a greater role for parataxis, and a clear link between the written mode and the rhythms of natural spoken discourse. ${ }^{19}$ John Knox's public writings are good examples of Scottish Senecan prose ${ }^{20}$ exemplified by the opening of what is arguably Knox's most famous (and notorious) work, The First Blast of the Trumpet against the Monstruous Regiment of Women (1558):

VVonder it is, that amongest so many pregnant wittes as the Ile of greate Brittanny hath produced, so many godlie and zelous preachers as England did somtime norishe, and amongest so many learned and men of graue iudgement, as this day by Iesabel are exiled, none is found so stowte of courage, so faithfull to God, nor louing to their natiue countrie, that they dare admonishe the inhabitantes of that Ile how abominable before God, is the Empire or Rule of a wicked woman, yea of a traiteresse and bastard[.]

By contrast with Pitscottie's "Chronikles," which circulated in manuscript, punctuation in the printed, public text of Knox's First Blast has been deployed to assist the reader. However, this opening sentence is hardly "well-formed" to modern tastes, lacking the pithiness and balance that have been held appropriate in formal written prose since at least the eighteenth century. The difference is reflected in the interpretation of the comma mark; if the comma is interpreted in present-day terms-that is, grammatically, as flagging a subordinate in relation to a main clause or, in pairs, as serving as an alternative to parentheses - the usage is inappropriate. But if perceived rhetorically, as an indication of a minor pause in the spoken delivery or apprehension for which the passage seems to have been designed (we might note the interjection "yea"), the usage is clear and effective.

Close examination of the texts associated with the Bothwell controversy show that they are written in a "loose" manner close to the Senecan style adopted by Knox. We might examine, for instance, the opening of the broadside version of the June 11 proclamation: ${ }^{21}$

18. For an example, see Smith, Older Scots, 64-65.

19. Not discussed further here is what has been termed "baroque prose," a form of Senecan usage embellished by complex, Latinate vocabulary; a well-known Scottish practitioner of such prose was the seventeenth-century writer Sir Thomas Urquhart. See further Smith, Older Scots, 66-67.

20. See ibid., 61-67 and references there cited. The passage from Knox's First Blast is cited here from the transcript in ibid., 200.

21. This transcription is based on the photostat held in the National Library of Scotland, Edinburgh (hereafter NLS): F.6.b.7(18) (Aldis Updated, 66; ESTC citation number S124063, STC 21930). The only extant copies of the original proclamation are SP 52/13/54 and SP 52/13/55 in The National Archives, Kew. The editorial principles adopted in this diplomatic transcription are those outlined in 
We of the Nobilitie and counsall dois zow to wit fforasmekill as the Quenis | Maiesteis maist Nobill persoun is and hes bene deteynit in captiuitie and thral $=\mid$ dome be a lang space bygaine, quhairthrouch hir hienes is nather habill to gouerne hir| Realme and subiectis be the aduise of the Nobilitie and subiectis thairof, nor 3 it to tak | tryall of that maist cruell and abhominabill murthour committit vpone hir lait husband | our Soueraine Henrie Stewart of gude memorie.

If we follow present-day prescribed standards and accept the deployment of the period as a marker of the completion of a sentence, the first "sentence," running from "We of the Nobilitie" to "of gude memorie," is not a sentence at all, since no clear grammatical object for the transitive verb "wit" ("know") is offered. After the initial statement that the "Nobilitie and counsall" wishes the reader of the document "to wit," we move to background information introduced by "fforasmekill" ("inasmuch"); since what the reader is "to wit" is not provided, by modern prescribed standards the sentence is not complete. Similarly lacking in grammatical cohesion, it could be argued, is the second "sentence" in the passage:

In respect of the quhilkis this our | haill Realme of Scotland is sclanderus and abhominabill to all Natiounis, and the / exampill of the misdeidis and attemptatis committit alsweill aganis our Souerane | Ladyis maist Nobill persoun: As in the persoun of our vmquhile Soueraine Lord | murtherit remaning as 3 it vnpunissit, and na apperance of remedie to be had or proui $=\mid$ dit thairinto geuis occasioun to the subiectis of this Realme, and oppinnis ane windo / vnto thame to perpertrat and commit maist heynous offencis and crymis aganis vthe $=\mid$ ris, Swa that in effect na persoun within this Realme takis thocht quhat vnhappy | deid he sall tak vpone hand, quhilk with continewatioun of tyme appeiris to grow to $\mid$ sic misordour that na man of quhatsumeuer qualitie he be of salbe assurit to liue accor $=\mid$ ding to Justice.

This "sentence" ranges widely from the general (that the whole realm of Scotland is "sclanderus and adhominabill" to all nations, or that no person within this realm "takis thocht [stops to think] quhat vnhappy deid [deed] he sall tak vpone hand") to the specific (that the person of our former "murtherit" sovereign lord remaining as yet unpunished opens a window ["oppinnis ane windo"] for them to perpetrate and commit "maist heynous offencis"). The subordinating constructions used (In respect of the quhilkis, As, Swa that, quhilk) are also hard to parse according to modern

Smith, Older Scots, 71-74, and based with modifications on those recommended by Simpson, Scottish Handwriting. No emendation is offered. The punctuation (or lack thereof) of the originals is reproduced as exactly as possible; line divisions are indicated with a vertical line (i.e., |). I have retained the obsolete letter yogh, as in " 3 it." 
notions of "well-formedness." The syntax of the passage is therefore "loose" in the Senecan manner. Nevertheless, the meaning of the passage is clear: the killing of Darnley shames the nation, and the failure to pursue his murderers is giving rise to a host of evils.

And close examination shows that the punctuation deployed in the broadsheet does indeed follow contemporary practice. John Hart's fine work on the reform of writing-systems, An Orthographie of 1569, may be used as a benchmark for such usage:

At last, to be readye to enter into my newe maner of writing, I will brieflye write of distinction or pointing, which (well obserued) maye yeelde the matter, much the readier to the senses, as well to the eie as to the eare.

Hart emphasizes how punctuation aligns with meaning ("how to vnderstande what is written") but he also emphasizes that punctuation "sheweth vs how to rest." He illustrates the latter with his discussion of the comma, which "is in reading the shortest rest, neare the time of a Crachet in musicke, alwayes signifying the sentence vnfinished." For Hart, speech and writing are very closely aligned, as may be noted from the subtitle of his work: "to write or paint thimage [the image] of mannes voice."22

In sum, Hart's recommendation is that texts should be presented with an eye for oral delivery, and this is the case with the broadsheets. They were designed to be read aloud, doubtless primarily by the "Maser or officiar of armes at ye marcat croces" who were charged with delivering the views of the Privy Council to the wider populace. In the following passage from the printed proclamation of June 26 , the audience for the text is implied: those who might be enticed into supporting the errant earl. The proclamation warns that, although Bothwell had in "cowartlie" fashion refused battle and is now condemned as guilty of Darnley's murder through the testimony of his own servants, he and his supporters ("pertakers") nevertheless sought to "perswade \& entyse simple and Ignorant men" to assist him. Recognizing that such "simple and Ignorant men" might be deceived, however, the broadsheet goes on to explain how such deception may be opposed through "oppin proclamatioun":

Thairfoir the Lordis of secreit counsall | ordanis ane Herauld or vther Officiar of armis, to pas to the mercat Croce of the | Burgh of Edinburgh, and all vthers placis neidfull within this Realme, and thair | be oppin proclamatioun to mak publicatioun heirof, to all our Soueranis leigis, | that nane pretend Ignorance of the samin, and to command and charge all the said | leigis of quhat estate or degre that euer thay be of, that nane of thame tak vpone | hand to resset or supplie the said Erle in thair housis

22. John Hart, An Orthographie, conteyning the due order and reason, howe to write or paint thimage of mannes voice, most like to the life or nature (London, 1569); the discussion of punctuation appears on sigs. Mir-M3v. For further discussion of such matters, see the important study by Elspeth Jajdelska, Silent Reading and the Birth of the Narrator (Toronto, 2007). 
or vtherwayis, to support him | with men, armour, hors, shippis, boittis, or vther furnessing quhatsumeuer be sey| or land, vnder the paine to be repuite, haldin and estemit as plaine pertakaris with / him in the said horribill murther, rauissing and vthers wickit crymes and ennor=| miteis committit be him, and to be persewit thairfoir as comon innimeis of this | commounweill. ${ }^{23}$

The job of the "Herauld or vther Officiar" is clear: he is to manage the situation, ensuring that the "simple and Ignorant" understand and actively support "the Lordis of secreit counsall" in turning away from Bothwell, on pain of being considered his accomplices: those who "plaine pertakaris" with him in Darnley's "horribill" murder, the abduction and rape ("rauissing") of Mary, and other "wickit crymes." Such accomplices, the proclamation warns, will be pursued "as comon innimeis of this commounweill." That the proclamation was to be made at the Mercat Cross where executions customarily took place would have added special force to this advice.

Comparison of the proclamations with their source texts in the "Register" shows some fascinating difference-not in terms of the words used but in presentation. The following passage from the proclamation of June 11 represents a diplomatic edition of the manuscript original, showing the same passage given above from the printed version. ${ }^{24}$ The principles followed are, with some minor exceptions, those developed by Grant Simpson for transcribing Scottish documents, and the purpose is the same: "to show the reader as exactly as possible what the writing in each document was intended to represent." 25

WE of the nobilitie \& counsall dois zow to wit fforasmekle as the quenis | maiesteis maist nobill persoun is and hes bene detenit in captiuitie and thraldome | be a lang space bygane quhairthrow hir hienes is nowther abill to governe hir | realme and subiectis be ye avyis of the nobilitie and subiectis yairof Nor 3 it to $\mid$ tak tryall of yat maist cruell and abhominabill murthour committit vpoun hir lait | husband oure souerane henrie stewart of gude memorie In respect of ye quhilkis | yis haill realme of scotland is sklanderous and abhominabill to all nationis | And ye exempill of ye misdeidis and attemptattis committit alsweill aganis our souerane | ladiis maist nobill persoun As in ye persoun of vmquhile our souerane lord murtherit | remaining as 3 it vnpunissit and na apperance of remedie tobe had nor provydit | yairvnto gevis occasioun to ye subiectis of yis realme And oppynnis ane wyndo / vnto yame to perpetrat and commit maist

23. The copy consulted is contained within Adv 33.2.31, NLS, a compilation including both manuscript and printed materials. Folio 141r consists of the Lekpreuik broadsheet (Aldis Updated, 67; ESTC citation number S95096, STC 21932); the Aldis Updated catalogue indicates that this is the only surviving copy.

24. See p. 231.

25. Simpson, Scottish Handwriting, 47. 
haynous offences and crymes aganis vyeris | Swa yat in effect na persoun within yis realme takkis thocht quhat vnhappy deid he sall| tak vpoun hand quhilk with continewatioun of tyme apperis to grow to sic misordour | yat na man of quhatsumeuer qualitie he be of salbe assurit to leif according to $\mid$ iustice. $^{26}$

Although the phraseology of the original has been reproduced with some care in the broadside, there are clear differences in presentation between the two texts. The printed text deploys a battery of marks of punctuation, ranging from the punctus through the comma and colon to capital letters, and including hyphens (=) to assist the reader in transitions from line to line. By contrast, the manuscript text uses punctuation much more sparingly, deploying litterae notabiliores to mark individual subsections of the argument and reserving the punctus for the conclusion of what might be termed the opening sententia-that is, "the utterance or complete rhetorical structure which expresses a single idea." 27 It is noticeable that the punctus in the manuscript after "iustice" is followed immediately afterward by another engrossed "WE," flagging to the reader that the next stage in the argument of the text is to follow: "WE yairfoir of ye nobilitie having ane speciall cair of ye deliuerance | of oure soueranes maist nobill persoun[.]" This use of engrossed letters to mark stages in an argument is common in the Privy Council "Register," 28 supported by the use of "yairfoir" [therefore] as a discourse marker. Such differences may be observed in all the texts transferred from "Register" to broadside. ${ }^{29}$ Why were these different approaches to the texts adopted?

Various explanations are possible, but the most plausible is based on the different functions the two versions performed. The manuscript texts, as suggested above, form a record of decision-making; persons reading the texts after the meeting from which they derived would be practiced readers of such documents, able to find their ways round them using a fairly limited set of visual prompts, such as engrossed words. The marginalia may have had a subsidiary guiding function as well, although they seem to be addenda about actions to be taken; for example, the marginal note "Proclamation" indicates that one was to be produced. The "Register" may even have been originally envisaged as simply an aide-mémoire for those who had been present at the meetings, although it is likely_-in the manner of modern minutes-that it was also

26. PC1, vol. 5, p. 1, NRS. For principles of transcription adopted, see note 21 above. Simpson, Scottish Handwriting, had difficulties with end flourishes in handwriting, which he either expanded or marked with an apostrophe. I have adopted the former procedure when it seems etymologically appropriate but not added apostrophes to mark flourishes, which are very common, especially after $r$. These "otiose strokes" seem to be simply decorative; see The Sex Werkdays and Agis, ed. L. A. J. R. Houwen (Groningen, The Netherlands, 1990), 22 and nn. Some minor exceptions from Simpson's practice have been adopted in these transcriptions: expanded contractions are marked by italics (e.g., "commit"), and " $y$ " is used for both the letter $y$ and the letter thorn, which were written identically (see note 16 above). As in the printed text, yogh has been retained, e.g., in " 3 it."

27. Parkes, Pause and Effect, 306.

28. See Smith, Older Scots, 93.

29. See, for further examples, ibid., 89-92. 
conceived of as a way of recording the presence of those taking part, requiring them to take corporate responsibility for difficult decisions: a crucial requirement for responsible politicians acting as best they could, according to their lights, amid the worrying complexities of the real world. The engrossed letters would allow for swift identification of key stages in the decision-making process.

The printed texts, however, were public documents designed for much wider consumption. The expression "oppin proclamatioun," found in several of the texts, is in this context interesting, since it seems to correlate both with public declamation and with the exhibition of printed versions in public places. Their posting on the Edinburgh Tolbooth and comparable venues across Scotland meant that they would have had to be reshaped for consumption by unpracticed readers or even by illiterate audiences to whom such documents were to be read aloud by the "officiar" or "heraulde." These last would themselves need clear guidance, expressed through commas, hyphens, and so on, to ensure a strong public performance. Later broadsheets would be designed for performance, like musical scores; it seems likely that these earlier broadsheets were similarly designed for an oral culture. Indeed, it would seem that the authorities would have wanted as many people to know the contents of these texts as possible-and especially "the simple and Ignorant men" referred to in the June 26 proclamation. The fact that the authorities thought it worth converting their decisions into printed format indicates that they were keen to have their point of view and decision-making widely disseminated. They needed the "public" on their side.

The differences can be perceived through the comparison of two versions of the proclamation of June $12.3^{3}$ Here is the opening of the "Register" text:

The quhilk day ye lordis of secreit counsale and nobilitie vnderstanding That| James erll bothuile put violent handis in oure sourane ladiis maist nobill persoun| vpoun ye xxiiij day of apprile lastbipast And yaireftir wardit hir hienes in $\mid$ ye castell of Dunbar quhilk he had in keping and be a lang space yaireftir| convoyit hir maiestie invironned with men of weir and sic freindis and kynnismen| of his as wald do for him euir in sic places quhair he had maist dominioun| and power hir grace beand destitute of all counsale and servandis Into ye quhilk| tyme ye said erll seducit be vnlesum wayis oure said souerane to ane vnhonest| mariage with him self quhilk fra ye begynning is null and of nane effect for sindrie| causs knawin alsweill to vyeris nationis and realmis As to ye inhabitantis of | yis commoun weill And als expres contrair ye law of god and trew religioun| professit within yis realme quhilk yai ar in mynd to manteine to ye vttirmest point| of yair lyff[.]

Litterae notabiliores are deployed, but nothing else, and the gaps between each are quite long; the reader needs to follow the text with care to apprehend its meaning, and the 
demands placed on the reader's skills of interpretation are (as will be apparent to a modern reader) rather considerable. By contrast, here is the opening of the same passage in the broadsheet:

THE quhilk day the Lordis of secreit counsale \& Nobilitie vnderstanding, That Ja-|mes Erle Bothwell put violent handis in oure Souerane Ladyis maist Nobill per-|soun vpon the xxiiij. day of Aprill last bypast, \& thaireftir wardit hir hienes in the Ca-|stell of Dumbar quhilk he had in keping, \& be ane lang space thairefter conuoyit hir| Maiestie inuironit with men of weir, and sic freindis and kinnismen of his as wald| do for him euer in sic places quhair he had maist dominioun and powar, hir grace be-|ing destitute of all counsale \& seruandis into the quhilk tyme the said Erle seducit be| vnlesum wayis oure said Soueraine to ane vnhonest mariage with him self, quhilk| fra the beginning is null \& of nane effect for sindrie causis knawin, alsweill to vther| natiounis and Realmes as to the inhabitantis of this commoun weill, and als expres| contrare to the Law of God and trew Religioun professit in this Realme quhilk thay| ar in mynde to mantene to the vttermost poynt of thair lyfe.

In this version, care has been taken to deploy commas to flag intermediate stages in the "thought" or "idea" of which the sentence consists. Commas are therefore being used in the manner approved by rhetoricians, to flag "a minor disjunction of the sense where it may be necessary to pause," 31 "alwayes signifying the sentence vnfinished." 32 The reader is therefore assisted in figuring out how the sentence as a whole is structured, allowing clarification of the overall "thought" or "idea": namely, the description of Bothwell's wicked behavior.

The reason for presenting the broadsheet texts in this way is therefore fairly transparent: it would have been important to the authorities that they remain in control of the interpretation of events, and that the texts be presented as clearly as possible. It therefore seems plausible to argue that the introduction of punctuation and other presentational features in the broadsheet versions of these documents relates closely to the need to supply a controlled, authoritative, interpretative apparatus. As Parkes has stated, the "primary function [of punctuation] is to resolve structural uncertainties in a text." 33 As just illustrated, comprehending the texts as they appear in the manuscript "Register" would have demanded considerable skill. In texts of acute political sensitivity, such as the broadsheets relating to the Bothwell crisis, it would have been crucial, from the perspective of those authorizing their public delivery, to minimize any opportunities for unfortunate ambiguity caused by such "structural uncertainties." Just as the Privy Council "Register" represented an attempt to professionalize government, so the 
printing of the documents derived from it represents an attempt to manage the news. And for both developments, there are, of course, intriguing present-day parallels. 34

\section{寉}

The insights arrived at above would not have been possible without direct consultation of the original manuscript and broadsheets rather than the edited Register of the Privy Council, and recent work on the editorial process has become much more conscious of the issues involved in the imposition of modern punctuation. As Sherman has stated, "I initially found the process of updating the pointing in the early printings [of Shakespeare, Jonson and Marlowe] liberating and satisfying, delivering the clarity and speed that effective modern punctuation is capable of providing. But the more editing I do, the more unsettling I find the license I have been given and the liberties I have taken with it." 35 As Sherman goes on to argue, "When we modernize the punctuation in Renaissance plays or poems, we are not so much replacing one system with another as taking texts from a culture where two (or more) different systems are in open and often ambiguous play into a culture where one has won out." 36 This play of systems is well illustrated by the manuscript and broadside versions of the Bothwell proclamations.

More generally, examination of the various versions of these texts demonstrates that punctuation is a vector of meaning in the complex, historically situated communicative relationships that exist between readers, copyists (whether scribes or printers), editors, and authors. Such a focus on communicative relationships relates rather well to the subdiscipline known as historical pragmatics. Historical pragmatics is an approach to texts from the past that over the last two decades has drawn on the increasing availability of electronic corpora, with an understandable focus on quantitative analysis. Recently, however, such analyses are being increasingly complemented by qualitative, contextually informed research that may be termed "new philological" - that is, focused on textual particularities, drawing on notions from book history, and asserting that the form of a text reflects its sociocultural function. Such a recuperation of philology — what might be termed the "new, new philology"demands a close attention to the particular circumstances of texts while bearing constantly in mind larger linguistic frameworks. What at first sight might seem trivial details, such as punctuation, appears on close examination to align with texts' sociocultural functions. 37 And this alignment is made especially salient in cases of textual

34. Readers wishing to examine complete versions of the manuscript and broadside versions of the June 12th proclamation may note that they appear, in the same format as presented here, in Smith, Older Scots, 89-92.

35. Sherman, "Punctuation as Configuration," 11.

36. Ibid., 919.

37. "New philology" was a nineteenth-century phenomenon; see Hans Aarsleff, The Study of Language in England, 1780-1860 (Princeton, N.J., 1983). Historical pragmatics is a comparatively new discipline; the range of subjects covered can be assessed from recent numbers of the Journal of Historical 
mouvance, as texts move through time and space and from medium to medium. Such correlations are well exemplified by the Bothwell materials. These correlations are of very considerable interest not only to scholars working within the paradigm of historical pragmatics but also, more generally, to literary scholars, would-be editors, and historians. They remind us not only of the importance of marks left by readers for reconstructing histories of reading and reception, ${ }^{38}$ but also of minutiae within the texts themselves, such as those phenomena studied in this essay.

I am much indebted to Alan Bryson and Cathy Shrank for their shrewd and illuminating suggestions for the improvement of this essay. Any remaining errors and infelicities are my own.

N Jeremy J. smith, Professor of English Philology at the University of Glasgow, has published widely on the history of English and Scots. His current project, funded by the Leverhulme Trust, is on the afterlives of medieval texts, focusing on formal features of the kind discussed in the current essay.

Pragmatics; for an authoritative overview by two leading practitioners, see Andreas Jucker and Irma Taavitsainen, English Historical Pragmatics (Edinburgh, 2012). For the recuperation of philology as "new" or "material," see most famously the essays in the journal Speculum for 1990, edited by Stephen Nichols; see also Bernard Cerquiglini, Eloge de la variante (Paris, 1989). For a study dealing with earlier texts and pursuing other issues raised in this essay, see Jeremy Smith, "The Evolution of Old and Middle English Texts: Linguistic Form and Practices of Literacy," in Imagining Medieval English, ed. T. W. Machan (Cambridge, 2016), 34-53. On mouvance, see famously Paul Zumthor, Essai de poétique médiévale (Paris, 1972).

38. For which, see most famously William Sherman, Used Books: Marking Readers in Renaissance England (Philadelphia, 2008). 